Section 1.

\title{
INTERNATIONAL COOPERATION
}



Jarosław Jańczak, PhD

Faculty of Political Science and Journalism

Adam Mickiewicz University, Poznań

\title{
BORDERS AND BORDER DIMENSIONS IN EUROPE. BETWEEN FRONTIERISATION AND BOUNDARISATION
}

\begin{abstract}
The main dimensions of border studies in European border studies include phantom borders, geopolitical boundaries, internal Schengen frontiers and external Schengen boundaries. They have been identified as a result of applying various scales/levels of analysis and the time-analysis perspective. They also constitute the main determinants of further development of the field, as well as an accurate classification of the dimensions in border studies.
\end{abstract}

Key words: border studies, frontierisation, boundarisation, phantom borders, geopolitical boundaries, internal Schengen frontiers and external Schengen boundaries.

\section{Introduction}

A look at the evolution of the political concept of the border - from tribal borders through the Roman limes, the medieval rule of loyalty in exchange for land, to imperial, national and power-political borders - shows changeability over time [12, pp. 243-253]. Similarly, further academic reflection in this field has gone through successive stages where researchers have focused on various dimensions of the concept of borders. What dominated until the 1950s was mainly the historical-geographic approach and attempts at developing its typology. Then the focus shifted to the functional dimension of borders and a better political understanding of them. Since the ' 80 s, research has examined territorial identities, geographical approaches, social representation of borders and finally the ecopolitical dimension [14, pp. 608-610].

The revival of border studies over the past twenty years was brought about by its increasing analytical and practical importance. In both cases the weight placed on the concept is largely down to security consider- 
ations, ongoing ethnic-territorial conflicts/collaboration and - finally - maritime issues [7, pp. 654-659]. At the same time, however, it is believed that borders are a hangover from the past and their change - not only of their outer limits but also of their importance, form and understanding - is seen as interference in the past, which in turn affects the present $[17$, p. 8].

1989 saw a significant watershed in border studies, in changing both the interest in borders and the approach to this concept. Regarding the former, new developments in the area of border studies gave rise to a lively academic debate on the matter. The latter was deeply rooted in the specific circumstances under which borders changed following the fall of communism. While the 'border revolution' after World War I and World War II was conditioned by the will of the victorious powers (who as a result of peace conferences or political alliances shaped the borders of European nations), after 1989 the new political order was established from the bottom up (the winners did not impose their will) [17, p. 9].

The aim of this paper is to present the dominant research tendencies in border studies within the European context over the last two decades. It sets out to identify the determinants of developments in the field and how the dimensions of border studies could be classified. The thesis acknowledges the key influence of two factors: the scale/level of analysis and the time-analysis perspective. Methodologically, the paper is based on a comparative analysis of various studies within the field of border studies. It needs to be stated that the intention was not to elaborate an exhaustive description and explanation of all the research dimensions of the area in question, but rather to outline the most significant tendencies in its further development.

\section{Border legacy and border reality - between boundarisation and frontierisation}

As regards European borders, the last twenty years have been marked by two contradictory tendencies. On the one hand, some existing borders are being delegitimised, as occurred in the countries which arose from Yugoslavia's ruins, former Soviet republics, etc. [17, p. 10]. First and foremost, it is the effect of kindling, or rekindling of ethnical and cultural nationalisms seeking to review the territorial order, whereby political and national borders do not overlap. On the other hand, however, borders are 
being devalued, as a consequence of greater European integration and the lesser clout of nation-states, which in turn, in some cases, also leads to attempts at revising the territorial order. It manifests itself in the separatist tendencies displayed in Scotland, Catalonia, Flanders, etc. [17, p. 10].

Both the above-described processes are linked to the concept of the frontier and boundary as the two basic manifestations of a border. In practice, in the process of delimitation they may take the form of boundarisation (when the border corresponds closely to the boundary) or frontierisation (when the border only resembles the frontier).

To understand the essence of a border and the processes behind its change, the boundary-frontier division needs careful consideration.

A boundary is a mainly legal concept which separates state structures $[17$, p. 8]. Boundaries then are "sharply drawn lines that mark the limits of authority and ownership (...), marked, and managed, sometimes loosely and sometimes strictly in accordance with the various and changing purposes of the adjoining states" [4, p. 265]. The boundary not only separates from what is outside but at the same time bounds what is inside [15, pp. 269-270].

Frontier is a broader term. It applies to social, economic and political elements referring chiefly to borderland communities [17, p. 8]. As a result, frontiers are "zones of varying width, either political or cultural in nature" [4, p. 265]. Assimilation or even expansion by one of the dominating parties is becoming a common frontier occurrence [20, pp. 687-688]. Since the border is drawn in a way enabling interaction and contact between disparate systems, borderlands of new quality are emerging and they differ greatly from their interiors. Consequently, an opinion has been formed that a frontier is an antechamber to the territory proper [15, pp. 269-270].

The border tendencies mentioned at the beginning of this section (delegitimisation and devaluation) are connected to the processes of boundarisation and frontierisation. The first one refers to the creation of a state under the Westphalian order with a clearly defined space, authority and territorially circumscribed population. The process, initiated in Europe in the $17^{\text {th }}$ century, became particularly evident during the nation-state building processes (and is still ongoing in some cases). On the other hand, the previously mentioned devaluation of borders also prompts the erosion of boundaries formed in the process of (re)frontierisation. Limited border controls and the declining importance of borders lead to their increasing porosity, more intense interaction and consequently the emergence or reconstruction of the elements of a frontier. 
At the same time, nevertheless, the two processes unfold in a context of historical legacy, as well as in the actual border reality. Keeping in mind the historical origin of borders, both boundarisation and frontierisation reveal their two-fold nature. On the one hand, they reflect ongoing existing processes, therefore they constitute an element of a real policy specific to a time and place. On the other hand, however, they are - deliberately or not - set in a historical context where until recently borders served a different purpose, had a different form and ran along different lines. In some cases, borders were politically and historically sensitive issues, due to territorial disputes or recently reclaimed sovereignty. As a result, borders are defined in two ways: firstly as an element of current and real politics and secondly as an element of historical legacies.

\section{National and European perspectives on border change}

In Europe the dynamics of border change is driven by the scale/levels of analysis. At least two perspectives can be singled out, each defining border-related situations and processes differently: a national state perspective and a continental perspective (in some cases it can be reduced to the European Union).

In the case of a smaller scale of analysis, the border is connected with the state; it serves the state and defines the state. The functions of borders are derived from the functions of a state. They show power, authority, economic management, identity and culture [1, p. 39]. Borders favour homogenisation and standardisation of those elements within the political-territorial systems separated by borders. At the same time, however, the process encourages further diversity of the lands located on both sides of the border. This holds true for the standardisation and unification of legal, economic, social, cultural and language systems [4, p. 273]. Therefore, not only does the border mark the state's sovereignty, but also its statehood. It is limited by a borderland and understood as a "peripheral territory located on or near the boundary of a frontier, which symbolically marks the limits of influence transmitted by a variety of political, economic and cultural centres" [13, p. 133].

Enlarging the scale of analysis means applying the continental perspective of studying borders. State borders seem to be declining in importance when contrasted with the macro-level divisions related to civilisational borders, the definition of 'the end of Europe', as well as the 
lesser significance of inter-state borders. Furthermore, such a scale adjustment leads to a revision of the requirements for cross-border cooperation. Nevertheless, sometimes a state boundary separates linguistically homogeneous territories, revealing at the same time the historical uniformity of the now-divided provinces [4, p. 273]. This, for a change, defies the concept of a border as an indication of a state's control over a territory.

\section{Dimensions of border studies in Europe}

The correlation between the two presented perspectives - the time-analysis perspective and the scale/level of border processes - results in a four-field matrix showing the main dimensions of the border debate. They include phantom borders, geopolitical boundaries, internal Schengen frontiers and external Schengen boundaries respectively (Figure 1).

Figure 1. The dimensions of the border debate in Europe

\begin{tabular}{|c|c|c|c|}
\hline & \multicolumn{2}{|c|}{ Perspectives } \\
\hline & & State & continental \\
\hline \multirow{2}{*}{ border } & legacy & phantom borders & geopolitical boundaries \\
\hline & reality & internal Schengen frontiers & external Schengen boundaries \\
\hline
\end{tabular}

Source: Author's concept.

In the following sections all four dimensions will be discussed.

\subsection{Phantom borders}

Phantom borders manifest themselves on a state or interstate level in the context of border historical legacies. They can be defined as "political borders, which politically/legally do not exist anymore but seem to appear in different forms and modes of social action and practices today, as for example voting as one part of political behaviour" [18]. They can be observed in the case of states which used to be partitioned by other states. In spite of numerous homogeneities, such as ethnic, cultural or linguistic ones, new fault-lines were created between individual provinces as a result of the unification within the state units they belonged to. Nowadays, phantom borders manifest themselves as lines separating regions of disparate political preferences (pro-European Western Ukraine and 
pro-Russian Eastern Ukraine or liberal Western and Northern Poland versus conservative Eastern and Southern Poland), but also of different infrastructure resources, types of economy, etc. [22]. Internal cleavage along borders which used to divide a state leaves a significant mark on current political, economic and social processes. On the one hand, various attempts have been made to overcome old differences underlain by historical borders. On the other hand, however, as the process of regionalisation progresses, they are becoming grounds for evincing local diversity within the state.

\subsection{Geopolitical boundaries}

The second dimension of border studies is geopolitical boundaries. These are rooted in the border legacy and are relics from the former border status quo on a continental scale. European geopolitical boundaries include mainly the cold war border, in the form of the iron curtain, which has resulted in the east-west division. The areas are contradictory in terms of the political values upheld through history (democracy versus authoritarianism), economy (free market and high level of economic development versus centrally planned economy and developmental backwardness) and society (civil society versus homo sovieticus). The examination of geopolitical boundaries is always carried out on a macro scale, consequently it applies to the entire continent, or its significant part. It focuses on at least two elements: overcoming geopolitical divides and rekindling geopolitical divides.

Bridging the differences between the eastern and western parts of the continent became the main paradigm in cross-border relations after the collapse of communism in Europe and a guide in the integration and disintegration processes taking place there. On some occasions, for instance in the case of the Polish-German [21] border, the Italian-Slovenian border and in Berlin, the process was symbolically reduced to a specific place and local manifestations of continental divides. It was, at the same time, reflected in great political ideas such as "Europe's two lungs" [11]. Polish Prime Minister Donald Tusk, during the Polish Presidency of the European Union, claimed that in the context of the economic crisis, further debate on the east-west divide makes no sense. Today, in his opinion, Europe is split into the north (faring well in the crisis and able to respond constructively to the economic challenges of global processes) and the south (stuck in stagnation with no potential to overcome it). 
At the same time, however, geopolitical boundaries are being recreated in various forms. They may be a useful rhetorical device employed as a political expediency, which was the case of Donald Rumsfeld assessing the situation in Europe, divided by different outlooks on the Iraq war. He split the continent into Old and New Europe. The former denotes passivity and naivety in international relations; the latter, advocating the Iraq war, implied engagement and willingness to become involved in resolving problems. Russian tendencies to restore its empire fall under the same category. They manifest themselves in the concept of 'the near abroad', referring to countries which are formally independent but practically exist within the Russian sphere of influence. Academically, this mindset came to be represented by Samuel Huntington, through his concept of civilisational borders as new conflict lines, which also run across Europe [8].

\subsection{Internal Schengen frontiers}

Internal Schengen frontiers show another dimension of border studies. They are connected with the perspective adopted by individual states and reveal the border reality - currently unfolding border processes. There is a direct link between internal Schengen frontiers and the outcomes of European and EU integration.

It is notable that the border-building policy in the EU is conducted at cross-purposes. On the one hand, lifting border controls (serving the functions proper to a border) is an integration tool vital to implementing the four freedoms - the free movement of people, goods, services and capital. However, parallel to that, increasingly tighter security is seen as the essence of the integration, and borders and border controls constitute a key element of national security systems [17, p. 24]. Consequently, a clear division between internal and external borders proves to be a functionally effective compromise. As regards internal borders, there is a tendency towards lax border controls, whereas the external borders have been hardened progressively.

Internal Schengen frontiers date back to the myth of a borderless Europe which spread after 1989 [17, p. 8]. The collapse of communism and the victory of the Western political and economic order were supposed to end the era of conflicts and-according to the neoliberal logic of free trade - contribute to creating a new order based on democracy and the free movement of goods. Because of the universal nature of the new order, and for pragmatic reasons connected to free movement, borders became un- 
necessary, even undesirable. New types of divides, however, quickly revised the idea, deeming it a political myth which failed to resist new conflicts erupting along new fault lines. That said, through the liberalisation of the Schengen zone border policies, the EU - within its spatial and political reach - did manage to implement the scheme of a 'borderless world'.

The debordering caused by the Schengen Agreement was complemented by a series of tools designed to encourage and enable cross-border cooperation, mainly through the INTERREG initiative and European Territorial Cooperation objective, which is central to the European cohesion policy. The incentives to cross the steadily-eroding state boundaries brought about a gradual (re)frontierisation. It engaged authorities and local communities on two levels: local and regional. Weakening state borders can be achieved by town twinning $[10,16]$ or Euroregional cooperation. In institutional terms, it is represented by cross-border governance.

Town twinning was connected - among others - with border twin towns: towns located on two sides of a national border, which often - granted high border porosity - exist as interconnected organisms. In the border debate they are treated as 'laboratories of European integration' [6] where interactions between not only different cultural, legal and economic systems, but also between disparate government structures are tested in controlled conditions To serve more effectively their public (regardless of their internal or external focus) and political (related to conserving the hold on political power) purposes they need to form cross-border relations with their counterpart institutions across the border, thus vetting the possibilities of broader continental integration [6, pp. 1-5].

Euroregions represent a regional dimension of (re)frontierization, (re)establishing not only cross-border cooperation but also cross-border regions.

In case of both levels, two elements are worth mentioning. Firstly - as revealed by internal Schengen frontiers - as political borders erode, mental and economic borders gain in importance [5, p. 1]. Secondly, however, new borders have been replacing the ones already eliminated [1, p. 37].

\subsection{External Schengen boundaries}

The last dimension - external Schengen boundaries - once again is connected to the border reality; it offers, however, a continental perspective with a special reference to European integration. Fading internal borders and the (re)frontierisation - as expounded above - was 
bound to result in checks hardening at the external borders of the Schengen zone. Forming a separating line between outside and inside, they came to serve a function similar to that of a boundary in the state-building process.

The external Schengen border is consequently a boundary. However, it is worth noticing that, apart from the linear external border of the EU, it is also characterised by elements of informal borders [17, p. 28]. Accordingly, in the Eastern part of the continent, as well as in North Africa, the EU organises a space for protecting its security, through agreements between the countries in the region, aimed at cutting the influx of undesirable elements within its borders.

This conclusion prompts another statement strongly present in border studies: in its external relations the EU practically pursues four geostrategies: a networked (non)border, a march, a colonial frontier or limes [2, p. 528]. The first one consists in establishing contacts between various centres on both sides of the external border, thus building a collaborative network. The second one is a buffer space between the EU and other politically-economic spaces such as the Russian Federation. The third one is a line that separates "civilisation" from "uncivilised" space. It can be moved as a result of expansion and it is perfectly passable for cultural, political and economic influences. The fourth one is an impermeable line of separation.

Practically, EU border policy applies both the march and colonial frontier strategies in relations with its Eastern neighbours and the limes in the south. This is so because the Southern and the Eastern neighbourhood is subject to a separation process which arises from the logic of a boundary. Therefore, external EU policies are tasked with forming a ring of friends around the EU's space. For instance, the European Neighbourhood Policy is an attempt at preventing the re-emergence of the iron curtain. By means of cooperation mechanisms across the external borders of the $\mathrm{EU}$, on the one hand the EU's position as a guarantor of security is maintained, on the other hand, its isolationist nature is undermined. It also needs to be stated that attitudes among the European Union's neighbours significantly influence the nature and shape of the EU. "The ENP is an attempt to draw final borders, simultaneously leaving them relatively porous for interactions (...)" [3, pp. 116-117].

These briefly presented considerations regarding the forms and consequences of external Schengen boundaries make it possible to establish a geographical model of integration drawing on Westphalian, imperial, 
neo-medieval models [2, p. 523]. The first denotes a territory with a relatively uniform political, economic and social nature, circumscribed by boundaries. The second could be described as a series of ripples whose influence and participation in integration processes diminish as they move away from the centre. The third one is a network of relations between multiple centres of overlapping influences on both sides of the border. It would seem that the organisation of the external borders of the EU is dominated by the Westphalian and imperial models [2].

\section{Conclusions}

The considerations expounded above reveal the main research tendencies within border studies. It has been assumed that the scale/level of analysis and the time-analysis perspective determine the dimension of the development of this research area. Consequently, four main dimensions of border studies can be singled out: phantom borders, geopolitical boundaries, internal Schengen frontiers and external Schengen boundaries. The continental level of analysis points to the domination of boundaries (even though there are strong tendencies to eliminate the linear division created by the external Schengen border with a view to preventing a cold war scenario re-emerging). The state perspective nowadays is characterised mainly by frontiers resulting from ongoing (re)frontierisation and deboundarisation, as well as the devaluation of borders.

\section{References}

1. Alkan N., Borders in Europe // Borders of Europe, ed. N. Alkan - Bonn: Zentrum für Europäische Integrationsforschung, 2002. - p. 31-71.

2. Browning C., Joenniemi P., Geostrategies of the European Neighbourhood Policy // European Journal of International Relations - 2008. - № 3. - vol. 14. - p. 519-551.

3. Browning C., Christou G., The constitutive power of outsiders: The European neighbourhood policy and the eastern dimension // Political Geography - 2010. - № 29. - p. 109-118.

4. Custred G., The linguistic Consequences of Boundaries, Borderlands, and Frontiers // Journal of Borderland Studies - 2011. - vol. 26. - issue 3. - p. 265-278. 
5. Ehlers N., Buursink J., Boekema F., Introduction. Binational cities and their regions: From diverging cases to a common research agenda // GeoJournal - 2001. - № 54. - p. 1-4.

6. Gasparini A., European Border Towns as Laboratories of Differentiated Integration // ISIG Quarterly of International Sociology - 1999-2000. - № 4. - p. 1-5.

7. Grundy-Warr C., Schofield C., Forty Years on: Revisiting Border Studies. Reflections on the Relevance of Classic Approaches and Contemporary Priorities in Boundary Studies // Geopolitics - 2005. - vol. 10. - p. 650-662.

8. Huntington S., Clash of Civilizations - New York: Simon \& Schuster, 1996. $-367 \mathrm{p}$.

9. Jańczak J., Cross-border Governance in Central European Border Twin Towns. Between De-bordering and Re-bordering // De-bordering, Re-bordering and Symbols on the European Boundaries, ed. J. Jańczak - Berlin: Logos Verlag, 2011. - p. 37-52.

10. Joenniemi P., Sergunin A., When two aspire to become one: City-twinning in Northern Europe // DIIS Working Paper - 2009. - № 21. - p. 231-242.

11. John Paul II, Apostolic letter "Euntes in mundum", 1988. - 16 p.

12. Jones S., Boundary Concepts in the Setting of Place and Time // Annals of the Association of American Geographers - 1959. - vol. 49. - issue 3. - p. 241-255.

13. Kisielowska-Lipman M., Poland's Eastern Borderlands: Political Transition and the 'Ethnic Question' // Regional \& Federal Studies - 2002. - vol. 12. - p. 133-154.

14. Kolossov V., Theorizing Borders. Border Studies: Changing Perspectives and Theoretical Approaches // Geopolitics - 2005. - vol. 10. - p. 606-632.

15. Kristof L., The Nature of Frontiers and Boundaries // Annals of the Association of American Geographers - 1959. - vol. 49. - issue 3. - p. 269-282.

16. Lundén T., European Twin Cities: models, examples and problems of formal and informal co-operation // ISIG Quarterly of International Sociology 2004. - № 3-4. - p. 1-14.

17. O'Dowd L., Wilson T. Frontiers of sovereignty in the new Europe // Borders of Europe, ed. N. Alkan - Bonn: Zentrum für Europäische Integrationsforschung, 2002. - p. 7-30.

18. Phantomgrenzen in Ostmitteleuropa. Project of the Centre Marc Bloch, Berlin - www.phantomgrenzen.eu.

19. Perkmann M., Building governance institutions across European Borders // Regional and Federal Studies - 1999. - № 7. - vol. 33. - p. 657-667. 
20. Walters W., The Frontiers of the European Union: A Geostrategic Perspective // Geopolitics - 2004. - vol. 9, - № 3. - p. 674-698.

21. Zago M., Border between Eastern and Western Europe: Cooperation Old and New, Cooperation with and without Walls // ISIG Quarterly of International Sociology 1999-2000. - № 4. - p. 1-9.

22. Zarycki T., Politics in the periphery: Political cleavages in Poland interpreted in their historical and international context // Europe-Asia Studies - 2000. - № 52(5). - p. 851-873.

\section{Резюме}

Главные измерения border studies в исследованиях европейских грании это phantom borders, geopolitical boundaries, internal Schengen frontiers and external Schengen boundaries. Их обособление вытекает из наложения разных шкал/уровней анализа и временно-аналитических перспектив. Одновременно это главные детерминанты развития этой области, а также возможности классификации измерений border studies.

Ключевые слова: Исследование грании, frontierisation, boundarisation, фантомные границы, геополитические гранищы, внутренние и внешние гранищь группы Шенген. 